\title{
PENGARUH TERAPI BERMAIN PERAN TERHADAP PERILAKU ANAK DALAM UPAYA PENCEGAHAN DEMAM BERDARAH DENGUE (Studi di Sekolah Dasar Negeri 1 Bandung Kecamatan Diwek Kabupaten Jombang)
}

\author{
Muhammad Ainul Yakin ${ }^{1}$ Hindyah Ike $S^{2}$ Rastia Ningsih ${ }^{3}$ \\ ${ }^{12}$ STIKes Insan Cendekia Medika Jombang ${ }^{3}$ STIKes Borneo Cendekia Medika \\ Pangkalan Bun \\ 1email : $\underline{\text { ainulyakin11@gmail.com, }},{ }^{2}$ email : hindyahike@yahoo.com, ${ }^{3}$ email : \\ rastianingsih@gmail.com
}

\begin{abstract}
ABSTRAK
Pendahuluan, Masalah perilaku anak dalam upaya pencegahan demam berdarah dengue adalah membuang sampah sembarangan serta masih ditemukannya tempat perindukan dan perkembangbiakan nyamuk. Tujuan penelitian ini untukmenganalisa pengaruh terapi bermain peran terhadap perilaku anak dalam upaya pencegahan demam berdarah dengue. Desain, penelitian ini adalah pra eksperimen one group pre test post test design. Populasi semua siswa kelas 3-5 yang berjumlah 54 orang dengan jumlah responden 48 anak, Teknik pengambilan sampel adalah proporsional stratified random sampling. Variabel independen dari penelitian ini adalah terapi bermain peran dan variabel depeden adalah perilaku anak dalam upaya pencegahan demam berdarah dengue.Instrumen penelitian menggunakan kuesioner dan skenario dengan pengolahan data editing, coding, scoring, tabulating dan uji statistik menggunakan Wilcoxon $\alpha=0,05$. Hasil, penelitian perilaku anak dalam upaya pencegahan demam berdarah dengue sebelum terapi bermain peran sebagian besar negatif sejumlah 29 responden (60,4\%).Perilaku anak dalam upaya pencegahan demam berdarah dengue sesudah terapi bermain peran hampir seluruhnya positif sejumlah 37 responden $(77,1 \%)$. Hasil uji Wilcoxon menunjukkan $\mathrm{p}=0,000$ yang menunjukkan bahwa $\mathrm{p}<0,05$. Kesimpulan dalam penelitian ini adalah ada pengaruh terapi bermain peran terhadap perilaku anak dalam upaya pencegahan demam berdarah dengue.
\end{abstract}

Kata Kunci : Bermain Peran, Demam Berdarah, Perilaku

INFLUENCE OF PLAYING ROLESTHERAPYON CHILDREN BEHAVIOR IN PREVENTION EFFORTS DENGUE HEMORRHAGIC FEVER (Study at State Elementary School 1 Bandung Districts DiwekRegency Jombang)

\begin{abstract}
Children's behavioral problems in prevention of dengue hemorrhagic fever are littering and still finding breeding ground and mosquito breeding. The purpose of this study was to analyze the influence of role playing therapy on child behavior in prevention effort denguehemorrhagicfever. The design of this research is pre experiment one group pre testpost test design. The population of all 3-5 grade students, amounting to 54 people with the number of respondents 48 children. The sampling technique isproportional stratifiedrandomsampling. Independent variable
\end{abstract}


of this research is role playing therapy and depedent variable is children behavior in effort of dengue fever prevention. The research instrument used questionnaire and scenario with data processing editing, coding, scoring, tabulating and statistical test using Wilcoxon $\alpha=0,05$. Result of research of child behavior in effort of denguehemorrhagicfever before play therapy role mostly negative 29 respondents $(60,4 \%)$. Child behavior in prevention effort denguefever after therapy play almost entirely positive role of 37 respondents $(77,1 \%)$. Wilcoxon test results showp $=0,00$ $<\alpha(0,05)$. The conclusion in this research is there influence of role playing therapy to child behavior in effort of prevention denguehemorrhagicfever.

\section{Keywords: Role Play, Hemorrhagic Fever, Behavior}

\section{PENDAHULUAN}

(110 kematian) (Depkes RI, 2015, 20).

Berdasarkan data dari Dinkes Jawa

Masalah Dengue Hemorrhagic Fever (DHF) di Indonesia sampai saat ini cenderung meningkat angka kejadian yang dialami oleh masyarakat dan semakin luas penyebarannya (Djunaedi, 2010, 3). Masalah perilaku anak dalam upaya pencegahan belum bisa dipercaya untuk menangani masalah Dengue Hemorrhagic Fever (DHF) secara optimal. Hal tersebut tercermin dari perilaku anak di lingkungan sekolah yang banyak ditemui membuang sampah dan kaleng-kaleng bekas di sekitar sekolahan. Dimana hal tersebut dapat membantu perkembangbiakan jentik nyamuk Dengue Hemorrhagic Fever (DHF) yang dapat megakibatkan terjadinya berbagai penyakit yang disebabkan oleh nyamuk Aedes Aegypti (Pangemanan, 2012, 3).

Jumlah kasus kejadian Dengue Hemorrhagic Fever (DHF) di duniadiperkirakan 390 juta setiap tahunnya mencapai keberadaan > 100 negara (WHO, 2015,3). Sedangkan pada tahun 2015 ini sampai awal bulan April tercatat angka kesakitan Demam Berdarah Dengue sebesar 5,17 per 100.000 penduduk (13.031 kasus) dengan angka kematian sebesar $0,84 \%$
Timur kejadiaan kasus Demam Berdarah Dengue (DBD) mengalami peningkatan dibandingkan tahun lalu. Pada tahun lalu periode yang sama (Januari-November), ada 4.876 kasus. Sedangkan Januari-November tahun ini sudah 5.823 kasus (Dinkes Jatim, 2016, 1). Di Kabupaten Jombang pada tahun 2015 jumlah kasus Demam Berdarah Dengue sebesar 646 (Dinkes Jombang, 2015,27).

Di

KabupatenJombangpadatahun 2016 jumlah penderita Demam Berdarah Dengue sebesar 1143, sedangkan data tertinggi kasus Demam Berdarah Dengue pada tahun 2016 terdapat di Puskemas Cukir Jombang sejumlah 156 kasus (Dinkes Jombang, 2016).

Penyebab Demam Berdarah Dengue karena penularan virus Aedes Aegypti yang dilakukan oleh nyamuk betina karena hanya nyamuk betina yang mengisap darah. Infeksi virus dalam tubuh nyamuk dapat mengakibatkan perubahan perilaku yang mengarah pada peningkatan kompetensi vektor, yaitu kemampuan nyamuk menyebarkan virus (Anggraeni, 2010, 6-10). Perjalanan penyakit Demam Berdarah Dengue (DBD) mempunyai penyebaran yang sangat cepat dan dapat mengakibatkan kejadian yang 
sangat fatal bagi penderita jika mengalaminya penyakit tersebut (Widoyono, 2012, 110). Dampak primer dari kejadian penyakit Demam Berdarah Dengue (DBD) dan Dengue Syock Syndrome (DSS) adalah timbulnya penurunanan tekanan darah dan hemokonsentrasi yang diperoleh dari peningkatan akut permeabilitas vaskuler. (Novriani, 2010, 3).

Pencegahan penyebaran nyamuk Aedes Aegypti dapat dilakukan dengan cara pemberantasan sarang nyamuk, pengendalian secara kimia, secara fisika dan melakukan perubahan perilaku masyarakat untuk meningkatkan pengupayaan dalam pemberhentian sarang nyamuk. Dimana perubahan perilaku masyarakat dapat disalurkan kepada anaknya yang nantinya bisa diterapkan dalam lingkungan sekolah dan lingkungan tempat tinggalnya (Anggraini, 2010, 610). Upaya pencegahan penyakit Demam Berdarah Dengue pada di lingkungan anak sekolah bisa dilakukan dengan menerapkan terapi bermain peran agar anak bisa memahami upaya pencegahan Demam Berdarah Dengue. Dalam metode bermain peran dimana anak sekolah yang ditunjuk bisa melakukan kegiatan seperti memberikan penyuluh Demam Berdarah Dengue, serta sebagai pasien Demam Berdarah Dengue dan sebagai anggota anak yang tinggal dekat dengan pengguna Demam Berdarah Dengue. Kegiatan bermain peran tersebut nantinya dapat diajadiakn sebagai upaya pencegahan dan penanggulangan terhadap Demam Berdarah Dengue (Notoatmodjo, 2012,133-148).

\section{METODE PENELITIAN}

Jenis penelitian ini adalah pre eksperimental dengan one group pre test post test design. Populasi pada penelitian ini adalah anak di Sekolah Dasar Negeri 1 Bandung Kecamatan Diwek Kabupaten Jombang Tahun 2019 sebanyak 54 orang. Teknik sampling yang digunakan adalah proportional simple random sampling sehingga didapatkan sampel sebanyak 48 responden. Variabel independen terapi bermain peran dan variabel dependen perilaku anak dalam upaya pencegahan demam berdarah. Alat pengumpulan data berupa kuesioner dan skenario (Nursalam, 2013).

\section{HASIL PENELITIAN}

\section{Data Umum}

Tabel 1 Distribusi Frekuensi Responden Berdasarkan umur di Sekolah Dasar Negeri 1 Bandung Kecamatan Diwek Kabupaten Jombang 2019

\begin{tabular}{ccc}
\hline Umur & Frekuensi & $(\%)$ \\
\hline 9 tahun & 8 & 16.7 \\
10 tahun & 15 & 31.2 \\
11 tahun & 25 & 52.1 \\
Total & 48 & 100 \\
\hline
\end{tabular}

Sumber : Data primer 2019

Berdasarkan tabel 1 menunjukkan bahwa dari 48 responden sebagian besar berumur 11 tahun yaitu sejumlah 25 responden $(52,1 \%)$.

Tabel 2 Distribusi Frekuensi Responden Berdasarkan jenis kelamin di Sekolah Dasar Negeri 1 Bandung Kecamatan Diwek Kabupaten Jombang 2019

\begin{tabular}{ccc}
\hline JenisKelamin & Frekuensi & $(\%)$ \\
\hline Laki-laki & 17 & 35.4 \\
Perempuan & 31 & 64.6
\end{tabular}


$\frac{\text { Total }}{\text { Sumber : Data primer } 2019}$

Berdasarkan tabel 2 menunjukkan bahwa dari 48 responden sebagian besar berjenis kelamin perempuan sejumlah 31 responden $(64,6 \%)$.

\section{Data Khusus}

Tabel 3 Distribusi Frekuensi Responden Berdasarkan perilaku anak dalam upaya pencegahan Demam Berdarah Dengue sebelum terapi bermain peran di Sekolah Dasar Negeri 1 Bandung Kecamatan Diwek Kabupaten Jombang 2019

\begin{tabular}{ccc}
\hline Pre test & Frekuensi & $(\%)$ \\
\hline Negatif & 29 & 60.4 \\
Positif & 19 & 39.6 \\
Total & 48 & 100 \\
\hline Sumber : Data primer 2019
\end{tabular}

Berdasarkan tabel 3 menunjukkan bahwa dari 48 responden sebagian besar perilaku anak dalam upaya pencegahan Demam Berdarah Dengue sebelum terapi bermain peran sebagian besar negatif sejumlah 29 responden $(60,4 \%)$.

Tabel4 Distribusi Frekuensi Responden Berdasarkan perilaku anak dalam upaya pencegahan Demam Berdarah Dengue sesudah terapi bermain perandi Sekolah Dasar Negeri 1 Bandung Kecamatan Diwek Kabupaten Jombang 2019

\begin{tabular}{c|c|c}
\hline Post test & Frekuensi & $(\%)$ \\
\hline Negatif & 11 & 22.9 \\
Positif & 37 & 77.1 \\
Total & 48 & 100 \\
\hline \multicolumn{2}{l}{ Sumber : Data primer 2019 }
\end{tabular}

Berdasarkan tabel 4 menunjukkan bahwa dari 48 responden hampir seluruh perilaku anak dalam upaya pencegahan Demam Berdarah Dengue sesudah terapi bermain peran hampir seluruhnya positif sejumlah 37 responden $(77,1 \%)$.

Tabel 5 Tabulasi silang Pengaruh Terapi Bermain Peran Terhadap Perilaku Anak dalam Upaya Pencegahan Demam Berdarah Dengue di Sekolah Dasar Negeri 1 Bandung Kecamatan Diwek Kabupaten Jombang 2019

\begin{tabular}{|c|c|c|c|c|c|c|}
\hline \multirow[t]{3}{*}{ Pre test } & \multicolumn{4}{|c|}{ Post test } & \multicolumn{2}{|c|}{ Jumlah } \\
\hline & \multicolumn{2}{|c|}{ Negatif } & \multicolumn{2}{|c|}{ Positif } & \multirow[b]{2}{*}{$\sum$} & \multirow[b]{2}{*}{$\%$} \\
\hline & $\sum$ & $\%$ & $\sum$ & $\%$ & & \\
\hline Negatif & 8 & 16,7 & 21 & 43,8 & 29 & 60,4 \\
\hline Positif & 3 & 6,2 & 16 & 33,3 & 19 & 39,6 \\
\hline Total & 11 & 22,9 & 37 & 77,1 & 48 & 100 \\
\hline \multicolumn{5}{|c|}{ Uji wilcoxon $\mathrm{p}=0,000$} & $=0$ & \\
\hline
\end{tabular}

Berdasarkan hasil analisis menggunakan salah satu software komputer yaitu SPSS 16, didapatkan hasil uji wilcoxon adalah 0,000 , hal ini menunjukkan bahwa nilai $p<0,05$ maka $\mathrm{H}_{1}$ diterima dan $\mathrm{H}_{0}$ ditolak, atau dengan kata lain ada pengaruh terapi bermain peran terhadap perilaku anak dalam upaya pencegahan demam berdarah dengue di Sekolah Dasar Negeri 1 Bandung Kecamatan Diwek Kabupaten Jombang Tahun 2019.

\section{PEMBAHASAN}

\section{Perilaku anak dalam upaya pencegahan demam berdarah dengue sebelum terapi bermain peran}

Berdasarkan tabel 5.3 menunjukkan bahwa dari 48 responden sebagian besar perilaku anak dalam upaya pencegahan Demam Berdarah Dengue 
sebelum terapi bermain peran sebagian besar negatif sejumlah 29 responden $(60,4 \%)$

Menurut peneliti hasil tabulasi kuesioner pada soal nomer 4 pada parameter 2 dengan dengan rata-rata terendah yaitu 1,7 yang menyatakan bahwa responden kadang-kadang atau tidak pernah menutup tempat penampungan air di dapur. Begitu juga menurut peneliti anak kurang memahami atau mengetahui tentang upaya pencegahan demam berdarah dengue dengan benar seperti menutup tempat penampungan air. Serta responden yang kadang-kadang menutup tempat penampungan air di dapur dikarenakan responden masih belum bisa memahami pentingnya $3 \mathrm{M}$ plus untuk mencegah perkembangbiakan demam berdarah dengue, selain itu responden belum memahami adanya informasi yang telah diberikan oleh petugas kesehatan baik melalui pamflet, seminar kesehatan waktu disekolah.

Menurut Notoadmodjo, (2012, 133) Pencegahan demam berdarah dengue pada anak sekolah bisa dilakukan dengan menerapkan terapi bermain peran agar anak bisa memahami upaya pencegahan demam berdarah dengue. Dalam metode bermain peran beberapa anggota kelompok ditunjuk sebagai pemegang peran tertentu untuk memainkan peranan, misalnya sebagai penyuluh demam berdarah dengue, sebagai pasien demam berdarah dengue dan sebagai anggota anak yang tinggal dekat dengan pengguna demam berdarah dengue.

Perilaku anak dalam $\begin{array}{r}\text { upaya } \\ \text { penecegahan demam } \\ \text { berdarah } \\ \text { dengue sesudah terapi bermain } \\ \text { peran }\end{array}$

Berdasarkan tabel 5.4 menunjukkan bahwa dari 48 responden hampir seluruh perilaku anak dalam upaya pencegahan Demam Berdarah Dengue sesudah terapi bermain peran hampir seluruhnya positif sejumlah 37 responden $(77,1 \%)$.

Menurut peneliti sesudah terapi bermain peran siswa mendapatkan wawasan yang akurat terutama tentang cara pencegahan Demam Berdarah Dengue dengan benar, siswa juga mampu berfikir lebih tentang pentingnya pencegahan Demam Berdarah Dengue dan siswa juga mengetahui tentang dampak tidak dilakukan pencegahan Demam Berdarah Dengue yang berakibat pada penyebaran nyamuk Aedes Aegypti yang bisa mematikan, begitu juga perilaku anak dalam upaya pencegahan demam berdarah dengue bisa meningkat menjadi positif dikarenakan keberhasilan peneliti melakukan terapi bermain peran terutama cara upaya mencegah demam berdarh dengue dengan baik dan benar, sehingga bisa menurunkan angka kejadian demam berdarah dengue pada anak sekolah.

Menurut Notoadmodjo, (2012, 133) Pencegahan demam berdarah dengue pada anak sekolah bisa dilakukan dengan menerapkan terapi bermain peran agar anak bisa memahami upaya pencegahan demam berdarah dengue. Dalam metode bermain peran beberapa anggota kelompok ditunjuk sebagai pemegang peran tertentu untuk memainkan peranan, misalnya sebagai penyuluh demam berdarah dengue, sebagai pasien demam berdarah dengue dan sebagai anggota anak yang tinggal dekat dengan pengguna demam berdarah dengue. 


\section{Pengaruh terapi bermain peran terhadap perilaku anak dalam upaya pencegahan demam berdarah dengue}

Berdasarkan hasil analisis menggunakan salah satu software komputer yaitu SPSS 16, didapatkan hasil uji Wilcoxon adalah 0,000, hal ini menunjukkan bahwa nilai $\mathrm{p}<0,05$ maka $\mathrm{H}_{1}$ diterima dan $\mathrm{H}_{0}$ ditolak, atau dengan kata lain ada pengaruh terapi bermain peran terhadap perilaku anak dalam upaya pencegahan demam berdarah dengue di Sekolah Dasar Negeri 1 Bandung Kecamatan Diwek Kabupaten Jombang Tahun 2019. Data yang diperoleh 48 responden perilaku anak dalam upaya pencegahan Demam Berdarah Dengue sebelum terapi bermain peran adalah negatif meningkat menjadi hampir seluruh perilaku anak dalam upaya pencegahan Demam Berdarah Dengue sesudah terapi bermain peran adalah positif sejumlah 21 responden $(43,8 \%)$.

Menurut peneliti terapi bermain peran yang diberikan kepada anak bisa menambah wawasan tentang pencegahan Demam Berdarah Dengue, selain itu adanya terapi bermain peran anak bisa lebih memahami tentang pencegahan Demam Berdarah Dengue seperti menguras bak mandi 1 minggu sekali, mengubur kaleng-kaleng bekas, menutup tempat penampungan air, tidur menggunakan kelambu, sehingga anak-anak bisa melaksanakan upaya pencegahan Demam Berdarah Dengue dengan benar.

Menurut Notoadmodjo, (2012, 133) Pencegahan demam berdarah dengue pada anak sekolah bisa dilakukan dengan menerapkan terapi bermain peran agar anak bisa memahami upaya pencegahan demam berdarah dengue.
Dalam metode bermain peran beberapa anggota kelompok ditunjuk sebagai pemegang peran tertentu untuk memainkan peranan, misalnya sebagai penyuluh demam berdarah dengue, sebagai pasien demam berdarah dengue dan sebagai anggota anak yang tinggal dekat dengan pengguna demam berdarah dengue.

\section{KESIMPULAN DAN SARAN}

\section{Kesimpulan}

1. Perilaku anak dalam upaya pencegahan demam berdarah dengue sebelum terapi bermain perandi Sekolah Dasar Negeri 1 Bandung Kecamatan Diwek Kabupaten Jombang sebagian besar negatif $(60,4 \%)$.

2. Perilaku anak dalam upaya pencegahan demam berdarah dengue sesudah terapi bermain perandi Sekolah DasarNegeri 1 Bandung Kecamtan Diwek Kabupaten Jombang hampir seluruhnya positif $(77,1 \%)$.

3. Ada Pengaruh Terapi Bermain Peran Terhadap Perilaku Anak dalam Upaya Pencegahan Demam Berdarah Dengue di Sekolah Dasar Negeri 1 Bandung Kecamatan Diwek Kabupaten Jombang.

\section{Saran}

1. Bagi siswa yang menjadi petugas kesehatan di sekolah

Bagi siswa yang menjadi petugas kesehatan di sekolah diharapkan lebih meningkatkan penyuluhan tentang upaya pencegahan demam berdarah dengue melalui Usaha 
Kesehatan Sekolah (UKS) agar siswa-siswa dapat mengerti tentang pentingnya upaya pencegahan demam berdarah dengue sehingga kejadian dapat bisa dihindari.

2. Bagi institusi pendidikan

Sebagai wacana $r$
$\begin{aligned} & \text { umum } \\ & \text { diperpustakaan sebagai }\end{aligned}$
pengembangan
keperawatan khususnya tentang
pencegahan demam berdarah
dengue, serta sebagai acuan
mahasiswa tentang pengaruh terapi
bermain peran terhadap perilaku
anak dalam upaya pencegahan
demam berdarah dengue agar bisa
diterapkan secara menyeluruh.

3. Bagi peneliti selanjutnya

Hasil penelitian ini, dapat digunakan untuk peneliti selanjutnya dengan sempel yang lebih besar, jenis dan rencana peneliti yang berbeda serta menggunakan kelompok kontrol, peneliti selanjutnya juga diharapkan bisa menerapkan variabel lain yang mempengaruhi upaya pencegahan demam berdarah dengue seperti Simulation Games.

\section{DAFTAR PUSTAKA}

Anggraeni. 2010. Stop Demam Berdarah Dengue. Bogor. Publishing House

Depkes RI, 2015. Data Demam Berdarah Dengue di Indoenesia. http://pppl.depkes.go.id/focus?id 74. Diakses 15/03/2019

Dinkes Jatim. 2016. Jumlah kasus Demam Berdarah Dengue di JawaTimur. http://www.seputar- indonesia.com/news. Diakses 15/03/2019.

Dinkes Jombang, 2015. Kejadian Demam Berdarah Dengue di Jombang. Dinkes Jombang.

Dinkes Jombang, 2016. Kejadian Demam Berdarah Dengue di Jombang. Dinkes Jombang.

Djunaedi, 2010.Masalah Demam Berdarah Dengue di Indonesia. http://etd.eprints.ums.ac.id. Diakses 07/03/2019.

Djunaedi, 2010. Penyakit Demam Berdarah Dengue (DBD).http://journal.unipdu.ac.i d/index.php. Diakses 20/03/2019.

Notoatmojo, S. 2012. Promosi Kesehatan dan Perilaku Kesehatan. Jakarta: Rineka Cipta.

Novriani, 2010.Dampak DBD. http://download.portalgaruda.org /article. Diakses 15/03/2019.

Widoyono. 2012. Penyakit Tropis Epidemiologi, Penularan, Pencegahan dan Pemberantasannya. Jakarta. Erlangga. 